\title{
Spectroscopic characterization of polysilicon solar cells
}

\author{
S B MANAMOHANAN, $R$ K GARG, S PARTHASARATHI and \\ M M PRADHAN \\ National Physical Laboratory, Dr K S Krishnan Marg, New Delhi 110012, India \\ MS received 6 June 1994
}

\begin{abstract}
Polysilicon ingots were made by float zone, using solar grade silicon (SOG-Si) prepared by acid leaching of metallurgical grade silicon (MG-Si). Impurity contents of the MG-Si and SOG-Si were analysed by emission spectroscopy and Fourier transform infrared spectroscopy. The main metal impurities $\mathrm{Ca}, \mathrm{Al}, \mathrm{Fe}, \mathrm{Cu}, \mathrm{Mn}, \mathrm{Mg}, \mathrm{V}, \mathrm{Ti}$ and $\mathrm{Zn}$ and non-metal impurities $\mathrm{C}, \mathrm{O}$ and $\mathrm{B}$ present in the two types of samples were determined. Elemental analysis for a knowledge of the impurity content is important to correlate its effect on the spectral response and diffusion length of minority carrier, and to determine solar cell process reliability. Spectral response and diffusion length for float zone silicon solar cell have been determined.
\end{abstract}

Keywords. Polysilicon; solar cell; spectral response; diffusion length.

\section{Introduction}

Effects of impurities in polysilicon on solar efficiency parameters have been studied by many investigators (Hunt and Dosaj 1979; Koliwad et al 1979; Davis et al 1980; Pivac 1988). The principal effect of the impurities is a degradation of spectral response (SR), lifetime and diffusion length (DL) (Davis et al 1980). Solar-grade silicon (SOG-Si) was prepared from metallurgical grade silicon (MG-Si); float zone (FZ) and Czochralski (CZ) were prepared from SOG-Si. The relevant impurities in these grades of materials were characterized by emission spectroscopy and FTIR spectroscopy. Spectral response and diffusion length were determined for cells fabricated from FZ material.

\section{Experimental}

\subsection{Emission spectroscopy}

Emission spectroscopy characterization for R\&D programmes enables a multielement scan at reasonable cost (Wang 1968, 1972). The emission spectra were recorded using a C Z Jena PGS 2 plane grating spectrograph. The excitation unit was a Universal arc pulse generator UBI 2. The spectra of the samples and SiO standards from SPEX were recorded on AGFA-Gevaert 34B50 photographic plates.

Four categories of samples $S_{1}, S_{2}, S_{3}$ and $S_{4}$ were taken. $S_{1}$ represents MG-Si; $S_{2}$, $\mathrm{S}_{3}$ and $\mathrm{S}_{4}$ represent $\mathrm{SOG}-\mathrm{Si}$ after acid leaching with different acid concentrations. They were powdered and arced in specpure cavity electrodes from SPEX at $230 \mathrm{~V}, 8 \mathrm{~A}$.

\subsection{F TIR spectroscopy}

The spectra for oxygen and carbon concentrations were recorded with a Digilab FTIR spectrophotometer in the range $2000 \mathrm{~cm}^{-1}$ to $400 \mathrm{~cm}^{-1}$. As per the requirement of 
infrared measurements, the $\mathrm{FZ}$ and $\mathrm{CZ}$ silicon were taken in the form of wafers, and mirror polished on both sides to prevent scattering losses of the infrared.

\subsection{Spectral response}

The experimental set-up for the spectral response is the same as described elsewhere (Kishore et al 1989).

\section{Results and discussion}

\subsection{Material characterization}

Samples $S_{1}, S_{2}, S_{3}$ and $S_{4}$ were characterized by emission spectroscopy semiquantitatively for $\mathrm{Ca}, \mathrm{Fe}, \mathrm{Al}, \mathrm{Mg}, \mathrm{V}, \mathrm{Mo}, \mathrm{B}, \mathrm{Mn}, \mathrm{Ti}$ and $\mathrm{Cu}$. The impurity concentrations are given in table 1 . The table shows that the MG-Si $\left(S_{1}\right)$ is very impure. After acid leaching with aqua regia in three concentrations, the impurities in SOG-Si material $\left(\mathrm{S}_{2}, \mathrm{~S}_{3}, \mathrm{~S}_{4}\right)$ so obtained go below ppm detection levels except for traces of $\mathrm{Al}, \mathrm{Mg}$ and Ca.

Koliwad et al (1979) reported that the copper segregates at the grain boundary, and that the efficiency of fine-grained silicon solar cell increases with increase in copper content, whereas in coarse-grained silicon the efficiency decreases with increase in copper content.

The SOG-Si material was further processed by float zone to obtain FZ material, and by Czochralski to obtain $\mathrm{CZ}$. The $\mathrm{CZ}$ and $\mathrm{FZ}$ materials were characterized by FTIR spectroscopy for oxygen and carbon concentration (Pivac 1988). Oxygen is important, as the electrical conductivity of the material depends on oxygen concentration (Mead and Lowry 1980; Newman 1986; Pizzini et al 1990). Table 2 shows that the oxygen concentration in FZ material is less than half of the oxygen concentration in $\mathrm{CZ}$ material.

Table 1. Emission spectroscopic data for four samples of silicon (MGSi and $S O G-S i)$.

\begin{tabular}{lrrrr}
\hline & MG-Si & \multicolumn{3}{c}{ SOG-Si (after acid leaching) } \\
\cline { 2 - 5 } & \multicolumn{1}{c}{$S_{1}$} & $S_{2}$ & $S_{3}$ & $S_{4}$ \\
\hline $\mathrm{Ca}$ & 3000 & 300 & 100 & 50 \\
$\mathrm{Fe}$ & 2000 & ND & ND & ND \\
$\mathrm{Al}$ & 400 & 200 & 50 & 20 \\
$\mathrm{Mg}$ & 50 & 30 & 20 & 5 \\
V & ND & ND & ND & ND \\
Mo & ND & ND & ND & ND \\
B & ND & ND & ND & ND \\
Mn & 500 & ND & ND & ND \\
Ti & 500 & ND & ND & ND \\
Cu & 50 & ND & ND & ND \\
\hline
\end{tabular}

Values are in ppm; ND, not detected 
Table 2. FTIR analysis of silicon (CZ and FZ) samples.

\begin{tabular}{lcc}
\hline Samples & Carbon & Oxygen \\
\hline Silicon (CZ) & $5.83 \times 10^{17}$ atom $/ \mathrm{cm}^{3}$ & $8.94 \times 10^{17}$ atom $/ \mathrm{cm}^{3}$ \\
Silicon (FZ) & $6.60 \times 10^{17}$ atom $/ \mathrm{cm}^{3}$ & $4.18 \times 10^{17}$ atom $/ \mathrm{cm}^{3}$ \\
\hline
\end{tabular}

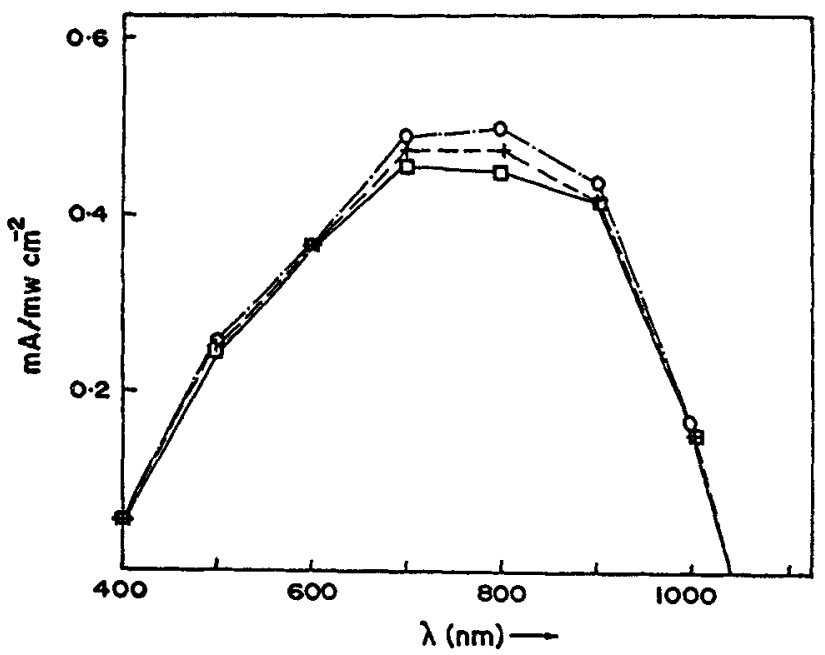

Figure 1. Spectral response curves for FZ silicon solar cells from bottom (- $\square-\square-\square-\square-$ ), middle $(--+-+\cdots+)$ and top $\left(-\cdots,-\cdot-O_{---}\right)$portions.

\subsection{Device evaluation}

The photocurrent measurement at each wavelength relative to the number of incident photons at that wavelength is the spectral response (SR) (Stokes and Chu 1977). SR provides us the most important diagnostic information for solar cell efficiency next to the $I-V$ characteristics (Gummel and Smits 1990). An accurate measurement of SR may be used to study cell quantum yield, degradation of minority carrier diffusion length (MCDL) and base material inhomogeneities (Wendy 1981).

The diffusion length (DL) can be obtained from SR values (Agarwala et al 1980). MCDL is an important parameter for optimizing the solar cell efficiency in the cell fabrication process. The DL is determined by plotting $\lambda / I_{\mathrm{SC}}$ against the reciprocal absorption coefficient $\alpha^{-1}$ of silicon, where $I_{\mathrm{SC}}$ is the short circuit current. $I_{\mathrm{SC}}$ is required in the evaluation of cells under development and production and also in the design of photovoltaic systems.

Spectral response measurements were done on three polysilicon solar cells fabricated as described by Jain et al (1981). The material for one solar cell was drawn from the bottom portion of the FZ material, the second cell from the middle, and the third from the top. SR curves are shown in figure 1. The curves show that for the bottom portion, the cell has the lowest $S R$ indicating that the impure fraction has accumulated at the bottom. The top portion cell has a higher SR indicating a higher 


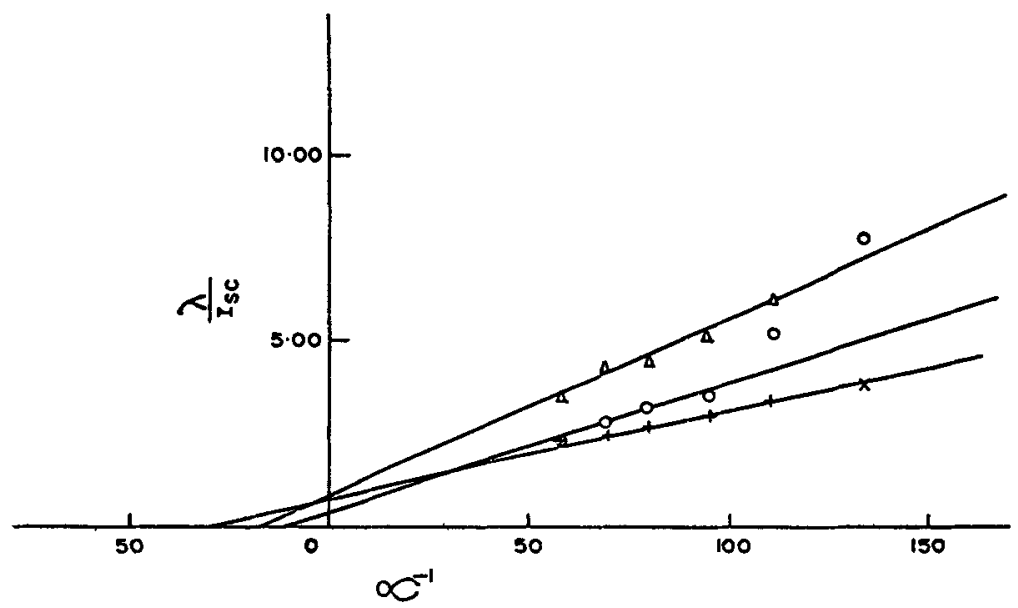

Figure 2. Minority carrier diffusion length (negative intercepts of $\alpha^{-1}$ axis) for FZ silicon from bottom (-O-O-O-O-), middle $(-\Delta-\Delta-\Delta-)$ and top $(-+-+-+-)$ portions.

purity. Thus there is a gradation of purity increasing from bottom to the top of the FZ material. The diffusion lengths DL of the above cells are shown in figure 2 as theintercepts in the negative axis of $\alpha^{-1}$. The value of DL is $25 \mu \mathrm{m}$ for the top portion cell, $13 \mu \mathrm{m}$ for the middle and $10 \mu \mathrm{m}$ for the bottom portion cell.

In conclusion, solar cells with higher spectral response and higher efficiencies can be obtained from the upper portion of $\mathrm{FZ}$ silicon material.

\section{References}

Agarwala A, Trivedi V K, Agarwala S K and Jain S C 1980 Solid-State Electron. 231021

Davis J D, Rohatgi A, Hopkins R H, Blais P D, Choudhury P Rai, McCormick J J and Mallonoff H C 1980 IEEE Trans Electron Devices ED27 677

Gummel H K and Smits F M 1990 Solar Cells 29103

Hunt L P and Dosaj V D 1979 Proc. 2nd E.C. Photovoltaic Solar Energy Conference p. 98

Jain G C, Singh S N, Kotnala R K and Arora N K 1981 J. Appl. Phys. 524821

Kishore R, Shastri V D P and Manamohanan S B 1989 4th International Photovoltaic Science \& Engg. Conference, Australia

Koliwad K M, Daud T and Liu J K 1979 Proc. 2nd E.C. Photovoltaic Solar Energy Conference p. 710

Mead D G and Lowry S R 1980 Appl. Spectrosc. 34167

Newman R C 1986 Proc. MRS Symposium p. 403

Pivac B 1988 J. Phys. D (Appl. Phys.) 211241

Pizzini S, Gandolfi A, Farina S and Branchforti M 1990 Mater. Sci. Eng. B7 69

Stokes E D and Chu T C L 1977 Appl. Phys. Lett. 30425

Wang M S 1968 Appl. Spectrosc. 22761

Wang M S 1972 Appl. Spectrosc. 26364

Wendy Ann Orr 1981 Characterization of materials and electrical properties of polycrystalline silicon for photovoltaic applications, Ph.D. T hesis, p. 34 